Aleksander A. Połonnikow

https://doi.org/10.26881/pwe.2020.49.02

ORCID: 0000-0002-1798-9949

Białoruski Państwowy Uniwersytet Pedagogiczny im. M. Tanka

alexpolonnikov@gmail.com

\title{
Holizm pedagogiczny i praktyki edukacyjne
}

\section{Summary \\ Pedagogical holism and education practices}

The subject of analysis in the article is the phenomenon of pedagogical holism, which is considered as a necessary condition for the organization and implementation of the pedagogical position. At the same time, orientation at pedagogical training towards one or another hypostatic integrity is considered as a condition limiting the creativity of students in the analysis and creation of qualitatively different forms of pedagogical thinking and activity. The creative position of future teachers is interpreted as one of the mechanisms ensuring overcoming the uniformity of the current education. Hypostasized forms of pedagogical holism are opposed by the discursive holism, which is associated with the refusal of pedagogical training from extra-situational support in the organization of pedagogical knowledge, the establishment of presentism ideology and the pedagogical relativism in educational practices. The operational unit of these practices is an utterance created in the acts of educational interaction. At the same time, the pedagogical utterance loses its dominant position associated with the status of the owner of the integrity of development and becomes one of the judgments in the multifaceted educational polylogue, existing as the integrity that arises in the actual educational interactions it produces.

Keywords: discursive holism, discursive ontology of education, discursive epistemology, discursive concept of the educational subject

Słowa kluczowe: holizm dyskursywny, dyskursywna ontologia edukacji, epistemologia dyskursywna, dyskursywna koncepcja podmiotu edukacyjnego

Tę małą rozprawę krytyczną można byłoby zatytułować nieco inaczej. Gdyby na przykład nadać jej tytuł: „Kształcenie pedagogiczne przyszłych nauczycieli w warunkach różnorodności wzorców działania i myślenia pedagogicznego", wówczas w centrum uwagi znalazłaby się dominująca dzisiaj postawa pedagogiczna, której kapitał symboliczny już stracił znacząco na wartości. Społeczeństwo ciągle stara się inwestować w nią najrozmaitsze zasoby, lecz jest niezmiennie rozczarowane niską skutecznością albo wręcz kontrproduktywnością swoich działań. Pozwala to dostrzec kryzys postawy pedagogicznej w tej jej wersji, która jest odtwarzana we współczesnej edukacji i zdaje się wymagać istotnej transformacji. 
Problem zidentyfikowania tej kwestii jest omawiany w pierwszej części artykułu i może być różnie rozwiązany. W pierwszym przypadku badacz dokonuje oglądu zjawiska przez pryzmat sali lekcyjnej, gdzie za pomocą obserwacji lub procedur eksperymentalnych bada przejawy relacji świadczące o pozycjach przyjmowanych przez uczestników procesu kształcenia lub im przypisywanych. W drugim zaś przedmiotem analizy staje się dyskurs pedagogiczny: wypowiedzi naukowców i praktyków, podstawy konstrukcji językowych, za pomocą których są konceptualizowane i ustanawiane fenomeny edukacyjne. Temu celowi najlepiej służą metody badawcze stosowane w narratologii i analizie dyskursu.

W niniejszym badaniu zostaje wykorzystane drugie z podejść metodologicznych, ponieważ autor podziela stanowisko Richarda Rorty'ego, zgodnie z którym rozwoju praktyk i nauk humanistycznych nie należy rozpatrywać przez pryzmat dążeń do coraz lepszego rozumienia, jak naprawdę się rzeczy mają, lecz jako „historię coraz bardziej użytecznych metafor" (Rorty 1996: 30). Wynika stąd, że przedmiotem rozważań jest nie dyskurs pedagogiczny „sam w sobie”, lecz są nim warunki, w których ulega on zmianom. Właśnie z takiej perspektywy przeanalizowano okoliczności przyjmowania określonych postaw pedagogicznych w procesie kształcenia. Konieczne jest przy tym uczynienie zastrzeżenia, że podjętych działań badawczych nie można oddzielić od osobistego zaangażowania autora (zob. Jabłońska 2006: 64).

Jednym z celów rozważań jest „nadanie ostrości” fenomenowi tzw. holizmu pedagogicznego ${ }^{1}$. Predykat ,pedagogiczny” wskazuje na specyficzne miejsce tej formy pojęcia w dyskursie edukacyjnym. Jej rolą jest zapewnienie jedności jego kształtu: spójności treści kształcenia, jednolitego obrazu przyszłości, powiązania nomosu i etosu interakcji pedagogicznej. Dzięki holizmowi występują w edukacji spójne relacje oraz solidarność poznawcza i praktyczna uczestników procesu kształcenia, staje się możliwe: połączenie funkcji kontroli społecznej i regulacji, określenie sposobu dystrybucji władzy oraz korelacja procesów semiozy edukacyjnej. Oznacza to, że holizm w edukacji spełnia wiele ważnych i korzystnych funkcji. Jednak - jak każda trwała struktura - może w warunkach niezbędnych zmian społecznych i edukacyjnych stać się czynnikiem hamującym lub odwracającym ich kierunek. Kwestie granic holizmu zostaną przedstawione w dalszej części niniejszego artykułu.

Druga część rozważań dotyczy formy twórczej aktywności, jaką jest szkicowanie. To metoda pracy z przyszłością, realizowana przed planowaniem i programowaniem. Pod względem psychologicznym jest ona bliska wyobrażaniu sobie czegoś, ale nie jest z nim tożsama, ponieważ jej podstawą nie jest pomysłowość jednostki, lecz stają się nią manipulacje semiotyczne, które mogą stymulować subiektywną kreatywność. Szkicowanie różni się od projektowania tym, że rezygnuje się w nim ze spełnienia warunku wykonalności. Kryterium oceny szkicowania jest skuteczność symboliczna rozumiana jako zdolność wy-

\footnotetext{
1 Termin pochodzi od gr. ó $\lambda \alpha$ ('cały') i pod względem organizacji semantycznej naśladuje organizmy żywe. Zakłada się, że całość może wywołać efekt agregacji (efekt systemowy), który przejawia się nie tylko przez uporządkowanie składających się na całość elementów, lecz i tworzenie nowej jakościowo całości, która jest czymś więcej niż prostą sumą wszystkich jej części (zob. Popper 1993: 26-27).
} 
tworzenia nowej wizji. Zagadnienia te rozwinięto w trzeciej części tekstu, zarysowując holistyczny szkic, który - jak się wydaje - może otwierać pewne perspektywy pedagogicznego projektowania.

\section{Składniki obowiązującego modelu holizmu pedagogicznego}

Zgodnie z definicją zamieszczoną w Encyklopedii pedagogicznej XXI wieku pedagogika holistyczna jest współczesnym, nowatorskim kierunkiem pedagogicznym o charakterze multidyscyplinarnym. „Dotyczy dogłębnego, wszechstronnego rozwoju człowieka, uwzględniając całokształt oddziaływań, zarówno zewnętrznych, jak i wewnętrznych. Uwzględnia zarówno uwarunkowania genetyczne, środowiskowe, instytucjonalne, jak i własną aktywność wychowanka wraz ze swoistością jego osobowości” (Szyszko-Bohusz 2005: 152). Pozwala to wnioskować, że oto pod nową nazwą nastąpiło odrodzenie dobrze znanej z historii pedagogiki nadziei na stworzenie uniwersalnej kartografii rozwoju człowieka. U podstaw tego zainspirowanego przez oświecenie nurtu pedagogicznego, często nazywanego pedologią, leżała po pierwsze wiara w istnienie jakiejś istoty człowieka, a po drugie pewność, że można lepiej poznać tę istotę przez połączenie terminów stosowanych przez różne dziedziny nauki, zdolnych całościowo przedstawić procesy ontogenezy i filogenezy. Ten pedologiczny eksperyment, jak świadczą źródła historyczne, skończył się klęską (Shvartsman, Kuznetsova 1994: 122).

Dzisiejsi zwolennicy ideologii ${ }^{2}$ holistycznej odwołują się do niej, argumentując to krytyczną oceną fragmentaryczności edukacji, którą cechuje jednostronność, intelektualizm oraz zapominanie o prawdziwej naturze człowieka. Absolutyzacja tej ostatniej kategorii wydaje się podstawą jednej z odmian holizmu pedagogicznego, którą umownie nazwę holizmem empirycznym, a za synonim tej cechy przyjmę w niniejszej analizie doświadczenie.

Ilustrację tego zagadnienia można znaleźć w pracy Moniki Grochalskiej (2015). W jej ujęciu holizm empiryczny bazuje na korelacji trzech H: Head, Heart, Hands (głowa, serce, ręce). Oznacza to, że uczniowie powinni aktywnie uczestniczyć w procesie nauczania, a oprócz wiedzy powinni posiąść też umiejętność głębokiego rozumienia stawianych im wyzwań. Do efektywnego uczenia się niezbędne są ich zaangażowanie emocjonalne oraz działanie (Grochalska 2015: 171). Warto podkreślić, że ani głowa, ani serce, ani ręka nie stanowią określonych jednostek strukturalnych, lecz za każdym razem są wykorzystywane jako zestawy interpretacyjne. W pewnym sensie to są puste znaczące ${ }^{3}$, które mogą być wy-

\footnotetext{
2 Poprzez ideologię rozumiem, podobnie jak Haydena White'a (2002: 42), zbiór przepisów uzasadniających zajęcie określonej pozycji we współczesnym świecie praktyki społecznej i zgodnego z nią działania (świat należy albo zmieniać, albo utrwalać jego dzisiejszy stan).

3 Puste znaczące to „teoretyczny model procesu konstruowania tożsamości zbiorowych zbudowany na poziomie społecznej ontologii i dla pedagogiki - jako dziedziny wiedzy, w której formowanie podmiotu zbiorowego jest stale obecnym wymiarem celów wychowania - ma to fundamentalne znaczenie. Zauważmy przy tym, że działanie pedagogiczne może być w tym wymiarze pojmowane jako tworzenie pustych znaczących - jako proces inwestycji w pragnienia »pełni społeczeństwa« w koncepty wynoszone na poziom etykiet zbiorowej tożsamości” (Szkudlarek 2012: 12).
} 
pełnione bardzo zróżnicowanymi znaczeniami i wartościami. W płaszczyźnie konceptualnej to wypełnienie zależy od kontekstu teoretycznego, ponieważ na przykład dla pedagogiki psychoanalitycznej najważniejszym elementem w triadzie Grochalskiej zawsze będzie serce (zob. Figdor 2000: 76), czego nie da się powiedzieć o podejściach opartych na „legendzie intelektualistycznej”4 lub sensualizmie w stylu Marii Montessori (2011: 59). Jednak dla analizy prowadzonej w niniejszym artykule ważniejsze są podjęte dalej kwestie.

Propozycja Grochalskiej nie tylko odwołuje się do obrazu jakiejś istoty psychofizycznej, lecz też, co najważniejsze, wprowadza w życie projekt pedagogiczny, w którego centrum znajduje się dziecko. Celem i wartością tego projektu jest autonomiczny i integralny podmiot, znajdujący w sobie podstawy do samoidentyfikacji. Kluczowym warunkiem samoregulacji jest w tym wypadku samopoznanie skierowane na wyjaśnienie swoich myśli i uczuć. Tego typu opisy zdolności jednostki do: ustalenia prawdy o sobie, działania na podstawie uzyskanej wiedzy oraz do podtrzymywania integralności swojego świata wewnętrznego powiązanej z całościowo postrzeganym światem zewnętrznym można znaleźć praktycznie we wszystkich kierunkach pedagogiki humanistycznej, której centrum stanowi dziecko (zob. Klus-Stańska 2018: 113). Podejścia te obowiązkowo konstruują scenę „wewnętrznego" życia człowieka, następnie lokując w nim instancje samozarządzające: „duszę”, ,jaźń”, ,ja” i tym podobne. Empiryczna ideologia holistyczna coraz częściej wykazuje swoją ograniczoność w warunkach współczesnego świata, w którym człowiek przestaje być panem swojego „świata wewnętrznego”, stając się programowany przez nowe technologie i anonimowe warunki interakcji międzykulturowej (Harari 2019).

Holizmowi empirycznemu, którego ilustrację stanowi podejście Grochalskiej, przeciwstawić można holizm transcendentalny w ujęciu Andrzeja Szyszko-Bohusza. Jako naukowiec wrażliwy na zachodzące we współczesnym świecie zmiany nie mógł on ignorować doświadczanego przez nas w ciągu ostatnich dziesięcioleci fenomenu globalizacji, przyczyniającego się do powstania m.in. problemu reprodukcji doświadczeń tożsamości grupowej i indywidualnej. „Nie ulega wątpliwości - pisze Szyszko-Bohusz - że współczesna cywilizacja naukowo-techniczna doby globalizacji znalazła się w szczególnie niebezpiecznym punkcie dziejów, spowodowanym głębokim kryzysem wartości społeczno-moralnych, etycznych, aksjologicznych. Przezwyciężenie tego kryzysu, stanowiącego aktualną groźbę totalnej autodestrukcji, leży w doskonaleniu osobowości ogółu obywateli świata, zwłaszcza decydentów, polityków, ekonomistów, wychowawców młodego pokolenia oraz ich rodziców. Zapewnienie bezpieczeństwa poszczególnych jednostek ludzkich, ich rodzin, również państw i całej ludzkości wiąże się nierozerwalnie z procesem samodoskonalenia osobowości, eskalacją poczucia odpowiedzialności nie tylko za rozwój własny, ale również za rozwój innych, za przyszłość świata" (Szyszko-Bohusz 2013: 215).

Szyszko-Bohusz lączy rozwiązanie problemu tożsamości z tą formą holizmu, która czerpie swoje uzasadnienia z uniwersalności chrześcijaństwa, łącząc z nim nadzieje na humanizm i naukowość pedagogiki: „Realną drogą realizacji tego fundamentalnego celu

4 Według ,legendy intelektualistycznej”, której interpretację zaproponował amerykański filozof G. Ryle, „robić coś rozumnie” oznacza „stworzyć trochę teorii, a następnie trochę praktyki” (zob. Kremer 2017). 
jest popularyzacja nowoczesnej, humanistycznej i holistycznej pedagogiki, opartej na nauce Największego Nauczyciela ludzkości - Mistrza z Nazaretu - Boga-Człowieka Jezusa Chrystusa" (Szyszko-Bohusz 2013: 215).

$\mathrm{W}$ analizie tej postawy interesujące jest nie tyle uzasadnienie wpisanych $\mathrm{w}$ nią oczekiwań, ile edukacyjne konsekwencje przyjęcia trancendentalnego ${ }^{5}$ podejścia holistycznego. $\mathrm{W}$ związku z tym warto wskazać trzy zagadnienia bezpośrednio związane $\mathrm{z}$ tym, co się dzieje w sali lekcyjnej. Pierwsze dotyczy zasad wyznaczających epistemologiczny porządek interakcji edukacyjnej. Wypowiedzi wygłoszonej z pozycji transcendentalnej (a właśnie ona stanowi centrum organizacji holistycznej) nie da się ani zweryfikować empirycznie, ani sfalsyfikować teoretycznie, ponieważ jest ona z natury postulatywna (aksjomatyczna). Wynika z tego, że semioza edukacyjna opiera się w znacznym stopniu na wierze, stanowiącej jej najważniejszy fundament. $Z$ tego powodu znane założenie pedagogiki holistycznej, które ustanawia komplementarną relację między nauczycielem a uczniem (zob. Szyszko-Bohusz 2005), może być zrozumiane jako psychologiczny warunek ich wzajemnego zaufania, a w konsekwencji - również jako programowanie bezkrytycznego podejścia ucznia do wypowiedzi pedagogicznej i inspirowanych nią warunków semiogenezy.

Druga kwestia jest związana $z$ organizacją komunikacji edukacyjnej i ustaleniem podzielanych przez społeczność naukową reguł współdziałania. Absolutyzacja instancji stojącej za wypowiedzią staje się warunkiem stosunków relewancji - ,jedyności desygnatu jako gwarancji możliwości osiągnięcia porozumienia, parytetu między partnerami’" (Lyotard 1998: 73). W przeciwnym przypadku, kiedy w komunikacji edukacyjnej przyjmuje się założenie o względności lingwistycznej jako regulatorze interakcji, wypracowanie postawy wspólnej dla grupy staje się problematyczne lub wręcz niemożliwe. W tym ujęciu holizm transcendentalny staje się komunikacyjnym mechanizmem produkowania nieracjonalnej solidarności lub homogenizacji grupy.

Trzecie z rozpatrywanych zagadnień dotyczy ustalenia w interakcji edukacyjnej specyficznego trybu postawy wobec siebie. Związek z takim czy innym autorytetem transcendentalnym zawsze ma charakter aksjologiczny. Wartości, które go warunkują, dysponują określoną mocą nakazową, organizując zachowanie jednostki w kierunku wskazywanym przez Absolut. Konstrukcje aksjologiczne (nakazy etyczne, estetyczne) z reguły mają naturę obrazową, a nie werbalną, co czyni je mało dostrzegalnymi dla refleksji intelektualnej i zarazem determinującymi samą aktywność refleksyjną. Doświadczenie studenta okazuje się zatem z góry zdeterminowane, a jego obiektywizacja jest ograniczona przez warunki realizacji holizmu transcendentalnego, ponieważ krytyczny stosunek do ustalonej całości wymaga wyjścia poza jej granice.

Podsumowując: rozpatrzone dotychczas formy holizmu pedagogicznego, zarówno empirycznego, jak i transcendentalnego, stając się warunkiem reprodukcji edukacyjnej, stabi-

\footnotetext{
5 W tym przypadku nie ma różnicy, co lub kto legitymizuje wypowiedź pedagogiczną: Bóg, Nauka, Przyroda czy Kultura; transcendentalność w kontekście edukacji będzie traktowana jako chwyt retoryczny, zapewniający absolutyzację podstaw wypowiedzi.
} 
lizują relacje istniejące $\mathrm{w}$ edukacji i tym samym stanowią poważną barierę dla zmian w jej obszarze. Właśnie ta sytuacja skłania do ich krytycznego przemyślenia i zredefiniowania.

\section{W stronę modelu holizmu dyskursywnego}

Jednym z kluczowych problemów, związanych z analizą całości, jest zagadnienie ich statusu ontologicznego. W rozważanym przypadku istnieją dwa opozycyjne wobec siebie rozwiązania. Pierwsze w najbardziej oczywisty sposób jest obecne w opracowaniach z zakresu psychologii Gestalt, przejmującej tezę Platona o świecie idei. Zgodnie z tym ujęciem „formy istnieją od samego początku, mogą one z łatwością nabrać znaczenia. Całość z jej wszystkimi właściwościami formalnymi jest już dana z góry i wtedy znaczenie jakby w nią »wchodzi«. A więc nic nowego w znaczeniu nie ma. Nie wnosi ono nic takiego, czego nie zawierałaby już od samego początku forma" (Koffka 1998: 331). Działanie całości jest tu zgodne z zasadami determinizmu strukturalnego. Jak ustalono w pierwszej części artykułu, integralna całość może być przypisana zarówno doświadczeniu jednostki, jak i apriorycznie uporządkowanej kulturze.

Drugie rozwiązanie ontologiczne przewiduje wyjściowy chaos, wywołany brakiem ustalonej z góry formy albo jej powstaniem połączonym z działalnością człowieka, społeczną organizacją i konstruowaniem. Forma jest zatem zawsze tworzona, a to, co zwolennicy jej aprioryczności przypisują zasadom istnienia wszechświata lub natury ludzkiej, warto rozpatrywać jako nastawienie ludzi, których nurtują poszukiwania i umacnianie niewzruszonych podstaw swojej działalności ${ }^{6}$. Pedagogika, która wykrywa niebezpieczeństwo hipostazy całości, koncentruje się na budowaniu dynamicznych ontologii, czyniąc fundamentem tej twórczej działalności kreatywne możliwości języka pedagogicznego. Ostrożnie rzecz ujmując, można stwierdzić, że chodzi tu o refleksję nad podstawami ustalania relacji pedagogicznych, rewizji ich źródeł i granic: „Tymczasem odwołując się do współczesnych XX/XXI-wiecznych form wiedzy i wyjaśnień metodologicznych, można odsłonić choćby w zabiegach dekonstrukcji, rekonstrukcji partykularne wartości, poprzedzające ową »ogólność«, »uniwersalność«, »całość«, »doskonałość« oraz wiedzę idealnych układów. I można wówczas odnaleźć zróżnicowanie społeczne, potoczne,

\footnotetext{
6 Zbliżony charakter ma wypowiedź T. Szkudlarka: „Zdecydowanie lepiej i przyjemniej jest bowiem postrzegać kulturę i edukację w świetle harmonii, koegzystencji, adaptacji, pozytywnej socjalizacji, interioryzacji odwiecznych wartości albo autentyczności osoby podążającej za naturalnymi impulsami rozwojowymi. Tego rodzaju dążenie, ta tęsknota do paidei ogarniającej całość kulturowego doświadczenia i w nim sytuującej dzieło wychowania, nie wygaśnie nigdy. Od pewnego czasu - zwykle określanego jako schyłek nowoczesności - niektórzy z nas zdają sobie jednak sprawę z przynajmniej tymczasowej nieprzystawalności tych wizji do realnej praktyki wychowania i uczestnictwa we współczesnej kulturze. Praktyka życia ludzkiego - jakkolwiek paradoksalnie to brzmi - nie jest bowiem harmonijnie spleciona z całością jego doświadczenia: bywa rozczłonkowana, chaotyczna, kierowana przypadkiem i zasadniczo »niekonieczna«. Wychowanie, jako praktyczna działalność, nie jest stopniowym »wtapianiem« człowieka w dobrze zhierarchizowaną i świadomą swej formy kulturę. Ono także podlega grze przypadku i różnicy, ono także w oczywisty sposób jest chaotyczne i niespójne samo ze sobą" (Szkudlarek 2009: 10).
} 
szczegółowe znaczenia rzeczywistości wychowawczych w różnych historycznych i geograficznych doświadczeniach ludzi, jako wartości pierwotne, poprzedzające wobec wartości uniwersalnych. Zdaniem E. Rewers to w zróżnicowanych wartościach partykularnych należy szukać znaczeń, wskaźników i określeń pierwotnych poprzedzających ogólne, uniwersalne znaczenia, kategorie, także te, które określają owe określone pais-ago" (Rodziewicz 2011: 31).

Podchodząc natomiast do tej kwestii bardziej radykalnie, można powiedzieć, że chodzi w niej o zróżnicowanie pedagogicznego myślenia i działania, w tym wyodrębnienie instytucjonalne „logosu posiadanego i replikowanego” oraz „logosu rozwijającego się i rozwijanego" (Schulz 2009: 213). To drugie z wymienionych podejść pedagogicznych otrzymuje nawet własną nazwę: „Nazwa alternatywna dla tego segmentu pedagogiki to: »logos symboliczny edukacji«, pedagogika form symbolicznych, pedagogika dyskursu, pedagogika mowy i pisma" (Schulz 2009: 213).

Przytoczone argumenty potwierdzają specyficzny zwrot dyskursywny w teorii i praktyce kształcenia pedagogicznego nauczycieli. Obejmuje on trzy podstawowe płaszczyzny relacji pedagogicznych: ontologię, epistemologię oraz podmiotowość edukacyjną. Dyskurs jest przy tym pojmowany nie tylko w kategoriach posługiwania się językiem, lecz również jako forma komunikacyjnej organizacji, poprzez którą urzeczywistniają się konkretne praktyki humanistyczne. W takim ujęciu rozwiązanie praktyczne staje się podstawą określenia granic rzeczywistości, ustalenia kryteriów prawdziwości i nieprawdziwości, reguł, działających w obszarze dyskursywnym. W konsekwencji edukacja staje się całością dyskursywną, choć kontrowersyjną. Działa ona jak system dystrybucji, który obejmuje jedne wypowiedzi i wyklucza inne. Jednocześnie dyskurs organizuje tryb realizacji wypowiedzi, ustalając powszechnie przyjęty styl ekspresywny. Zmiany w edukacji dostosowują się więc do modyfikacji stylistycznych, co można uznać za charakterystyczne dla całego dyskursu przygotowania pedagogicznego nauczycieli.

Dyskursywna ontologia edukacji pedagogicznej nauczycieli sugeruje przede wszystkim „desubstancjalizację otaczającego świata” (Petrova 2005: 183). W związku z tym faktom, wydarzeniom, relacjom i warunkom sytuacji edukacyjnych nadawana jest lokalizacja, co oznacza, że reguły i inne dyskursywne obowiązki są uznawane za zasadne tylko w obszarze aktualnej interakcji. Wszystkie fenomeny edukacji „istnieją” tylko w momencie występowania relacji edukacyjnych, konstruowanych przez wzajemne oddziaływanie jednostek, których pozycje określane są przez charakter ich wypowiedzi. $Z$ tej perspektywy nie każda wypowiedź w sytuacji edukacyjnej zyskuje status edukacyjnej. Jest on bowiem uwarunkowany jakościowym przekształceniem pozycji, z jakiej wypowiada się uczestnik, jego stosunkiem do charakteru własnych wypowiedzi i sytuacji komunikacyjnej w ogóle. Wypowiedź w ontologii dyskursywnej jest podstawowym elementem sytuacji edukacyjnej, jest jej jądrem i aktem. W tym przypadku o znaczeniu wypowiedzi decyduje nie tyle jej semantyka, ile pragmatyka i „działaniowe nastawianie języka” (Makarov 2003: 18). Przejście od postawy niedyskursywnej do dyskursywnego podejścia do języka jest fundamentalnym wydarzeniem, oznaczającym zmianę myślenia o całości i charakterze rozwoju sytuacji edukacyjnej. 
Epistemologia dyskursywna zasadza się na radykalnym prezentyzmie, czyli kładzeniu nacisku na teraźniejszość, co wymaga rozwiązania problemu referencji. Ponieważ w modelu dyskursywnym nie istnieje przestrzeń zewnętrznych odniesień dla zachodzącej interakcji, znaczenia występujące $\mathrm{w}$ komunikacji edukacyjnej są określane przez konkretną modalność „,dyskursu”, czyli sytuacyjnie, albo - jak określił to Harold Garfinkel - przez „indeksykalność znaczeń” (Garfinkel 2007: 13). Pozwala ona odróżnić wypowiedzi, które zależą od kontekstu, od wypowiedzi zdekontekstualizowanych. Znaczenie tych pierwszych zależy od okoliczności posłużenia się nimi i ,jest związane z tym, kto mówi, a ich wykorzystanie zależy od stosunku mówiącego do tego obiektu, do którego odnosi się słowo" (Garfinkel 2007: 13).

Wraz z sytuacyjną interpretacją znaczeń na pierwszy plan semiogenezy edukacyjnej wysuwa się swoista podejrzliwość semiologiczna, czyli krytyczne nastawienie, dzięki któremu „możemy przyjąć, że jedyne co jest »oczywiste« to »nieoczywistość« (»oczywista nieoczywistość «)" (Klus-Stańska 2012: 37). Jednak w kategorii zwrotu semiologicznego, realizowanego w krytycznej orientacji epistemologicznej, obecna jest jedna charakterystyczna cecha. Jest ona związana nie tyle z nieufnością wobec wiedzy i sposobu jej zastosowania $\mathrm{w}$ sytuacji edukacyjnej, ile $\mathrm{z}$ własnym doświadczeniem odbierania i porządkowania informacji. Innymi słowy, spotkanie z samym sobą jako z problemem produkowania znaczeń może zostać uznane za kluczowe zadanie w rozwoju myślenia krytycznego przyszłych pedagogów.

To jednak nie wystarcza. Równie ważne jest krytyczne nastawienie wobec tej formy edukacji, która ukształtowała doświadczenie edukacyjne. Jest ona zwykle postrzegana przez uczestników procesu edukacyjnego jako naturalna, oddziałująca w sposób ukryty i - jak podkreśla Zygmunt Bauman - okazuje się aktualnym warunkiem, „wyjątkowo słabo związanym z realizowanym tematem nauczania" (Bauman 2005: 155). W tym kontekście najważniejszym epistemologicznym zadaniem i drugim pod względem znaczenia wydarzeniem edukacyjnym staje się nabranie dystansu do ukrytego programującego oddziaływania formy edukacyjnej.

Dyskursywna koncepcja podmiotu edukacyjnego jest związana z zadaniem przezwyciężenia przez uczestnika interakcji własnej tożsamości w jej naturalistycznym esencjalistycznym rozumieniu. Z perspektywy edukacji oznacza to oddzielenie ,ja" dyskursywnego od ,ja” psychofizycznego. Pierwsze (występujące w wypowiedzi) zaczyna funkcjonować jak pozycja zajmowana w komunikacji edukacyjnej przez podmiot mówiący. Oznacza to, że między psychofizycznym (materialnym) ,ja" a ,ja"-wypowiedzią ma powstać luka tworząca możliwość eksperymentowania z tym ewentualnym ,ja" w okolicznościach edukacyjnych. Pokonanie przez studenta związanego z tą sytuacją „kryzysu interpretacji” staje się kryterium skuteczności edukacyjnej. Dyskursywna koncepcja podmiotu zakłada rezygnację z wypowiedzi jako własności osobistej (reguła deprywatyzacji wypowiedzi). Ekspresywna interpretacja języka (gestu, ruchu) wchodzi w zakres analizy krytycznej, a mówiący uzyskuje status spełniającego wymagania dyskursywne. 


\section{Zakończenie}

Głównym problemem, który podjęto w niniejszym artykule, jest sposób posługiwania się zasadą holistycznej organizacji relacji edukacyjnych. Całość, apriorycznie postulowana w pedagogice, jest warunkiem formatowania rzeczywistości edukacyjnej statyczności i generowania dyskursywności niekwestionowanej w jej kontekście. Rozwój jednostki (dojrzewanie czy kształtowanie się) z reguły odpowiada tworzeniu integralnej całości lub zmianie jej rodzaju. $Z$ kolei forma tej całości jest atrybutem pozycji zajmowanej w relacjach pedagogicznych i fundamentalnym mechanizmem jej genezy. Integralność zapewnia więc prawomocność postawy pedagogicznej, w odniesieniu do której pozycja uczącego się (wychowanka) zawsze jest nie do końca uporządkowana lub niewystarczająca, a wręcz deficytowa. Właśnie ta dyspozycja pozwala nauczycielowi pełnić misję łącznika z przyszłością - przewodnika do „najlepszego ze światów”. Forma holistyczna, przyswojona $\mathrm{w}$ trakcie przygotowania pedagogicznego, jest odtwarzana $\mathrm{w}$ pedagogicznej działalności zawodowej absolwenta uczelni wyższej. To ona zapewnia ciągłość kształcenia nauczycieli i ich funkcjonowania zawodowego. Zmiana utrwalonego w procesie edukacji rodzaju myślenia o całości nie narusza samego mechanizmu reprodukcji pedagogicznej, lecz pozwala edukacji ujawnić pozorność jej jakościowych transformacji.

Zmiana w sposobie funkcjonowania edukacji - zgodnie z podstawowymi tezami niniejszego artykułu - jest związana ze zwrotem dyskursywnym. Oznacza to włączenie w przygotowanie pedagogiczne nauczycieli doświadczeń nabywanych podczas: 1. dekonstruowania konstruktów holistycznych, traktowanych jako produkty ideologii pedagogicznych, praktyk komunikacyjnych i retorycznych, osadzonych w określonych warunkach historycznych, kulturowych i edukacyjnych; 2. samookreślenia się w tych działaniach uczestników reprodukcji edukacyjnej. W takim przypadku fundamentem postawy, która będzie obejmować wszystkie holistyczne konstrukty, stanie się odwołanie do dyskursów pedagogicznych, stanowiące warunek nowego kreatywnego i profesjonalnego myślenia oraz działania pedagogicznego. Przyszły nauczyciel, zdolny do ujawnienia związku między swoim działaniem (wypowiedzią) a charakterem funkcjonowania relacji edukacyjnych, zyska status osoby dyskursywnie odpowiedzialnej i zorientowanej konstruktywistycznie.

Opracowanie językowe: Grażyna Szyling

\section{Literatura}

Bauman Z. (2005), Individualizirovannoye obshchestvo. Moskva, Logos.

Figdor G. (2000), Psikhoanaliticheskaya pedagogika. Moskva, Izdatel'stvo Instituta Psikhoterapii.

Garfinkel H. (2007), Issledovaniya po etnometodologii. Sankt-Peterburg, Piter.

Grochalska M. (2015), Idea edukacji holistycznej a gotowość na zmiany wśród nauczycieli bioracych udziat w projekcie „Umiem się uczyć” - refleksja krytyczna. „Forum Oświatowe”, 27(2). Harari Y.N. (2019), 21 urok dlya XXI veka. Moskva, Sindbad. 
Jabłońska B. (2006), Krytyczna analiza dyskursu: refleksje teoretyczno-metodologiczne. „Przegląd Socjologii Jakościowej”, 2(1).

Klus-Stańska D. (2012), Wiedza, która zniewala - transmisyjne tradycje w szkolnej edukacji. „Forum Oświatowe", 1(46).

Klus-Stańska D. (2018), Paradygmaty dydaktyki. Myśleć teorią o praktyce. Warszawa, Wydawnictwo Naukowe PWN.

Koffka K. (1998), Sila i slabost'geshtal 't-teorii psikhicheskogo razvitiya. W: V. Keller (red.), Osnovnyye napravleniya psikhologii v klassicheskikh trudakh. Moskva, Izdatel'stvo AST-LTD.

Kremer M. (2017), Ryle's “Intellectualist Legend” in Historical Context. „Journal for the History of Analytical Philosophy”, 5(5). https://jhaponline.org/jhap/article/view/3204/, 5.15.2017.

Lyotard J.-F. (1998), Sostoyaniye postmoderna. Moskva, Aleteyya.

Makarov M.L. (2003), Osnovy teorii diskursa. Moskva, Gnozis.

Montessori M. (2011), Vpityvayushchiy razum rebenka. Sankt-Peterburg, Volontery.

Petrova G.I. (2005), Sotsial'nyye kommunikatsii i kommunikativnaya ontologiya obrazovaniya. W: L.A. Verbitskaya (red.), Mezhkul turnyye vzaimodeystviya i formirovaniye yedinogo nauchno-obrazovatel'nogo prostranstva. Sankt-Peterburg, Politekhnika-servis.

Popper K. (1993), Nishcheta istoritsizma. Moskva, Progress-VIA.

Rodziewicz E. (2011), O metaforze „pais-ago” i przemieszczaniu jej znaczeń dzisiaj. „Przegląd Pedagogiczny", 1.

Rorty R. (1996), Sluchaynost', ironiya i solidarnost'. Moskva, Russkoye fenomenologicheskoye obshchestvo.

Schulz P. (2009), Wykłady z pedagogiki ogólnej. T. 3: Logos edukacji. Toruń, Wydawnictwo Uniwersytetu Mikołaja Kopernika.

Shvartsman P.YA., Kuznetsova I.V. (1994), Pedologiya. „Repressirovannaya nauka”, 2.

Szkudlarek T. (2009), Media. Szkic z filozofii i pedagogiki dystansu. Kraków, Oficyna Wydawnicza Impuls.

Szkudlarek T. (2012), Tożsamość. W: M. Cackowska (red.), Dyskursywna konstrukcja podmiotu. Przyczynek do rekonstrukcji pedagogiki kultury. Gdańsk, Wydawnictwo Uniwersytetu Gdańskiego.

Szyszko-Bohusz A. (2005), Pedagogika holistyczna. W: T. Pilch (red.), Encyklopedia pedagogiczna XXI wieku. T. 4. Warszawa, Wydawnictwo Akademickie Żak.

Szyszko-Bohusz A. (2013), Pedagogika holistyczna oraz samodoskonalenie osobowości i bezpieczeństwo $w$ dobie globalizacji. „The Polish Journal of the Arts and Culture”, 7(4).

White H. (2002), Metaistoriya: istoricheskoye voobrazheniye v Yevrope XIX v. Yekaterinburg, Izdatel'stvo UralGU. 